проблеми Украӥни: географічний аналіз та пошук шляхів вирішення. Херсон, 2013. С. 22-27.

2. Стадній А. Моделі дистанційного навчання. Актуальні питання гуманітарних наук. 2020. Вип. 29. Т. 4. С. 151-156.

3. Стрельбицька С. Взаємодія викладача зі студентами під час дистанційного навчання в освітньому просторі закладу вищої освіти. Збірник наукових пращь А'ОГОГ. 2020. С. 25-31.

DOI https://doi.org/10.30525/978-9934-26-110-7-80

\title{
РОЛЬ МУЛЬТИМЕДІЙНИХ ЗАСОБІВ У ПРОЦЕСІ ВИКЛАДАННЯ УКРАЇНСЬКОЇ МОВИ ЯК ІНОЗЕМНОЇ СТУДЕНТАМ МЕДИЧНОГО ПРОФІЛЮ НАВЧАННЯ
}

\author{
Козелко I. P. \\ кандидат філологічних наук, \\ старший викладач кафедри українознавства \\ Львівський національний медичний університет \\ імені Данила Галищького \\ м. Львів, Украӥна
}

У XXI ст. освіта в Україні спрямована на підготовку спеціалістів різних галузей науки, де на рівних правах здобувають свій фах вітчизняні та іноземні студенти. Значна частка іноземних громадян прагне здобути медичну освіту саме в Україні. Їхня увага прикута до діяльності науковців-медиків, а саме до процесу обміну інформацією з світовою спільнотою, що в умовах дистанційного навчання відбувається із залученням різних технологій навчання. Як відомо, на високому науковометодичному рівні проводиться навчання студентів-медиків також i y Львівському національному медичному університеті імені Данила Галицького, де «головним принципом підготовки лікарів є безперервність і багатоступеневість медичної освіти в залежності від обраної кваліфікації» [2, с.27].

3-поміж усіх дисциплін, що їх пропонують для студіювання у цьому університеті, чільне місце займає також предмет украӥнська мова як іноземна (далі УМІ). Зауважмо, що УМІ включено до освітніх програм більшості вузів України. На сьогодні викладачами розроблено чимало підходів, методів та методик до вивчення цієї дисципліни. Зокрема, Г.Строганова послідовно виклала концептуальні підходи на шляху до 
опанування УМІ. Вчена визначила, що важливими для мовної практики $є$ екстралінгвістичний, системний, функціональний, функціональностилістичний, функціонально-семантичний, функиіонально-комунікативний, структурно-семантичний, індивідуальний, особистісний підходи [4], які охоплюють реалізацію знань студента-іноземця у тісному зв'язку з позамовною дійсністю, а також функціональних зв'язків різних мовних рівнів та стилів з урахуванням формального вираження та значення пізнаваного, що відбувається з опертям на особисті якості студента та ставленні до нього як до окремого індивіда.

Для актуалізації системних знань мови, що $є$ іноземною для студента медичного університету, є дотримання підходів та методів взаємної аудиторної роботи викладача та студента. Зауважмо, що львівська дослідниця І.Кочан виокремила креативні, когнітивні, інтерактивні методи, рольові та лінгвістичні ігри, ситуативні вправи $і$ завдання, що базуються на основі комунікативного аспекту. Проте, вчена висловилась і про роль мультимедійних засобів для оптимізації процесу опанування мови, i наголосила, що «якісне викладання дисципліни не може здійснюватися без використання комп'ютерних технологій та системи Інтернет, де можна отримати найсучаснішу інформацію, активно спілкуватися з колегами та студентами» [3, с.19].

Мета розвідки - вказати на необхідності використання мультимедійних засобів на заняттях з УМІ як ключових у кадровій підготовці студентів-медиків на сучасному етапі навчання, а також вказати на доцільності їхнього використання.

Питання вивчення УМІ із залученням інноваційних засобів супроводжується тривалими науковими дискусіями між вітчизняними та зарубіжними викладачами-методистами. Проте у публікаціях не достатньо приділено уваги навчанню іноземця-медика УМІ із допомогою мультимедійних засобів, чим і зумовлена актуальність дослідження.

Вважаємо, що пошук оптимального шляху опанування мови в іншомовній аудиторії перебуває в статусі активного обговорення науковцями (Л.Антонів, Д.Мазурик, І.Кочан та інші). Так, викладачіметодисти все частіше намагаються впроваджувати традиційні методи навчання УМІ із інноваційними.

Праці, які розкривають зміст реалізації навчання іноземних студентів 3 УМІ 3 допомогою інформаційно-телекомунікаційних (ITКТ), і мультимедійних технологій в Україні вивчали: Д. Вертипорох, Р. Гуревич, Т. Коваль, Л. Мацько, Т. Кудіна, Н. Тимощук, О. Дакалюк, А. Гарник; за рубежем: М. Варшауер, С. Толмана, С. Торндайка, С. Трапезникова, Дж. Хартлі. 
Зокрема, Д.Вертипорох довів, що навчальний процес при застосуванні мультимедійних технологій буде успішним за таких дидактичних умов:

1. Розробка й апробація комп'ютерних навчальних програм з відповідної дисципліни;

2. Урахування рівня відповідності програмного забезпечення (ППЗ) загальнодидактичним вимогам і вимогам методики навчання конкретної навчальної дисципліни;

3. Урахування дидактичних можливостей мультимедійних технологій як засобу активізації навчально-пізнавального процесу;

4. Впровадження різноманітних мультимедійних форм і методів;

5. Урахування спеціальної підготовки викладача до застосування мультимедійних технологій [1, с.89].

За межами України, М.Варшауер - вчений Каліфорнійського університету, активно працює над впровадженням комп'ютерних технологій у навчальний процес, більше того, він надає мультимедійним засобам провідну роль в опануванні іноземної мови. Він $є$ автором книг, які якнайповніше передають підхід вченого до вивчення не рідної мови іноземцями: «Інтернет для викладання англійської мови», «Віртуальні підключення», «Телекалаборачія при вивченні іноземних мов», i «Мережеве викладання мови» тощо. М.Варшауер представив свої погляди щодо вивчення іншої мови, які базуються на комп'ютерному забезпеченні. Він виокремив три фази такого навчання: біхевіористичне, комунікативне та інтегративне [5].

Очевидним $є$ факт про те, що важливе місце, у вивченні УМІ іноземними студентами-медиками, посідає використання інноваційних технологій, залучення яких дозволяе оперувати технічними засобами навчання (комп'ютер, різні комп'ютерні програми, мультимедійна дошка, Інтернет). Тому, в науці прийнято говорити про мультимедійний nidxid (Т.Касьяненко) до навчання УМІ. Зокрема, переконливою вважаємо думку проте, що інноваційні технології сприяють розвитку та вдосконаленню усіх форм мовленнєвої комунікації (читання, говоріння, письмо, аудіювання тощо). Отже, раціональним $\epsilon$ використання технічної підтримки на заняттях з УМІ як для самостійної роботи студента, на що відводиться певна кількість годин, так і при груповому навчанні.

Підсумовуючи можемо ствердити про те, що мультимедійні засоби при викладанні УМІ мають певні переваги, аніж посібники чи підручники. Саме аудіо-візуальний формат здатен пробудити зацікавлення іноземного студента-медика до даної теми, що свідчитиме про ефективніший рівень проведення такого заняття. Такий вид 
діяльності покликаний сформувати мовну компетентність іноземцямедика.

Мультимедійні засоби доцільно використовувати для навчання іноземних студентів-медиків 3 точки зору ефективнішої організації навчального процесу, де відбувається пізнання системи мови, іiі мовної організації та реалізація набутих знань на практиці, як результат, мовна компетенція. Такі заняття сприяють подоланню мовних бар'єрів, розкривають творчий потенціал, найважливіше - мотивують іноземного студента-медика до продуктивної роботи.

Перспективним видається той факт, що викладачі, які обирають мультимедійний підхід для роботи 3 іноземними студентами-медиками на заняттях з УМІ, повинні також впроваджувати, описувати цей підхід і у посібниках та підручниках, над якими вони працюють.

\section{Література:}

1. Вертипорох Д. Дидактичні умови застосування мультимедійних технологій у навчальному процесі ВНЗ. Гуманізація навчально-виховного процесу. Слов'янськ, 2012. Випуск LIX. C. 82-90.

2. Грищук M.I. Науково-методичні основи викладання фундаментальних дисциплін іноземним студентам-медикам. Медична освіта. 2012. № 3. С. 27-29.

3. Кочан I. Нові технології в практиці викладання української мови як іноземної. Теорія і практика викладання української мови як іноземної. 2008. Вип. 3. С. 14-20.

4. Строганова Г. Концептуальні підходи до засвоєння української мови іноземними студентами. Теорія $і$ практика викладання украӥнської мови як іноземної. 2008. Вип. 3. С. 173-179.

5. Warshauer M. Computer Learning Networks and Student Emprowerment. System. 1996. № 24. P. 1-14. 